\title{
Influence of operating parameters on treatment of egg processing effluent by electrocoagulation process
}

\author{
R. Sridhar • V. Sivakumar • J. Prakash Maran • \\ K. Thirugnanasambandham
}

Received: 20 July 2012/Revised: 9 January 2013/ Accepted: 23 April 2013/Published online: 23 May 2013

(C) Islamic Azad University (IAU) 2013

\begin{abstract}
The treatment of egg processing effluent was investigated in a batch electrocoagulation reactor using aluminum as sacrificial electrodes. The influence of operating parameters such as electrode distance, stirring speed, electrolyte concentration, $\mathrm{pH}$, current density and electrolysis time on percentage turbidity, chemical oxygen demand and biochemical oxygen demand removal were analyzed. From the experimental results, $3-\mathrm{cm}$ electrode distance, $150 \mathrm{rpm}, 1.5 \mathrm{~g} / \mathrm{l}$ sodium chloride, $\mathrm{pH}$ of 6 , $20 \mathrm{~mA} / \mathrm{cm}^{2}$ current density, and 30-min electrolysis time were found to be optimum for maximum removal of turbidity, chemical oxygen demand and biochemical oxygen demand. The removal of turbidity, chemical oxygen demand and biochemical oxygen demand under the optimum condition was found to be 96,89 and $84 \%$, respectively. The energy consumption was varied from 7.91 to $27.16 \mathrm{kWh} / \mathrm{m}^{3}$, and operating cost was varied from 1.36 to $4.25 \mathrm{US} \$ / \mathrm{m}^{3}$ depending on the operating conditions. Response surface methodology has been employed to evaluate the individual and interactive effects of four independent parameters such as electrolyte concentration (0.5-2.5 g/l), initial pH (4-8), current density (10-30 mA/ $\mathrm{cm}^{2}$ ) and electrolysis time (10-50 min) on turbidity, chemical oxygen demand and biochemical oxygen demand removal. The results have been analyzed using Pareto analysis of variance to predict the responses. Based on the analysis, second-order polynomial mathematical models were developed and found to be good fit with the experimental data.
\end{abstract}

R. Sridhar · V. Sivakumar $(\bowtie) \cdot$ J. Prakash Maran .

K. Thirugnanasambandham

Department of Food Technology, Kongu Engineering College,

Perundurai, Erode 638052, TN, India

e-mail: drvsivakumar@yahoo.com
Keywords Aluminum electrode $\cdot$ Biochemical oxygen demand Chemical oxygen demand Current density . Turbidity

\section{Introduction}

The egg processing industry is a water-intensive industry, it generates more than 10 billion liters of effluent annually, and it has high organic loads due to presence of egg proteins (Xu et al. 2001, 2002). The volume of effluent generated and its characteristics normally depend on the process used for egg processing. The effluent, which is generated from all the process stages mainly, contains detergent, chemicals, egg proteins and fats. High concentrations of organic components in effluent streams involve a serious environmental problem and must be properly treated before discharge from the environment. The State Pollution Control Board of Tamil Nadu, India, has directed the industries to implement zero discharge facilities.

An extensive literature analysis has been made, and it is found that only a few authors have made an attempt to study the treatment of egg processing effluent. Bough (1975) studied the treatment of wastewater generated from egg breaking section using chitosan as an coagulation and reported that 70-90\% total solids and 55-75\% chemical oxygen demand (COD) were reduced depends on the process conditions. Bulley (1976) used aluminum sulfate as a coagulation agent to treat egg processing wastewater using and reported that the total solids was removed $38-92 \%$ and biochemical oxygen demand $\left(\mathrm{BOD}_{5}\right)$ was 80-89\% depend on the quantity of coagulant added. Harris and Moats (1975) investigated to recover egg solids from egg processing wastewater and reported more than $90 \%$ $\mathrm{BOD}_{5}$ and $97 \%$ COD reduction. Xu et al. (2001) studied 
the treatment of egg processing wastewater using different coagulants such as lignosulfonate, bentonite, carboxymethylcellulose and ferric chloride for simulated and industrial wastewater and found that chemical oxygen demand, turbidity and total solids were reduced over 90, 97 and $95 \%$, respectively, for all coagulants. Xu et al. (2002) studied the recovery of protein from simulated and industrial egg processing wastewater using electrocoagulation method and reported that digestibly of protein and fats recovered from settled solids was good. From the analysis of literature, it is found that though some authors made an attempt to recover protein from egg processing effluent, detail extensive work has not been reported for treatment of effluent function of fundamental and operating variable.

Conventionally, the industrial effluents are treated by many different techniques such as adsorption, membrane filtration, coagulation-flocculation and advanced oxidation processes such as ozone, photochemical and Fenton's method, etc. (Akyol et al. 2004; Ersoy et al. 2009; Minhalma et al. 2006; Zhang et al. 2006) to remove COD, $\mathrm{BOD}_{5}$ and color. These technologies require an extensive setup for treatment of effluent. Moreover, each step takes place in a separate tank, and the entire treatment requires several $\mathrm{pH}$ adjustments as well as the addition of chemicals. These conventional processes generate a considerable quantity of secondary pollutants and large volumes of sludge which needs further treatment. The biological treatment processes are more suitable for treatment of high-strength organic effluent when two-stage (anaerobic + aerobic) treatment technique is used. (Kalyuzhnyi et al. 2005). The drawbacks associated with the conventional and biological techniques forced the effective treatment method for complete degradation of pollutants. In recent years, electrocoagulation process has been attracting a great attention for treatments of industrial effluents such as poultry slaughterhouse (Bayramoglu et al. 2006), cork process (Beltran de Heredia et al. 2004), yeast industry (Kobya and Delipinar 2008), dairy industry (Tchamango et al. 2010), olive mill (Un et al. 2006) and distillery industry (Yavuz 2007), etc., because of the flexibility and the environmental compatibility. Electrocoagulation technique has some advantages compared to conventional methods such as easy to operate, less retention time, reduction or absence of adding chemicals, rapid sedimentation of the electro-generated flocs and less sludge production (Holt et al. 2005). In order to develop an electrocoagulation process for egg processing effluent, the fundamental and operating variables, which affect the removal efficiency and operating cost, have to be optimized. Hence in the present study, the effects of the operating parameters such as electrode distance, stirring speed, electrolyte concentration, initial $\mathrm{pH}$, current density and electrolysis time using aluminum electrodes are investigated in detail, and energy consumption and operating costs were calculated. Box-Behnken design was also employed to develop mathematical models for describing the interactive effects of electrolyte concentration, initial $\mathrm{pH}$, current density and electrolysis time on the performance of an electrocoagulation process for the treatment of egg processing effluent. The present research was carried out in the Department of Food Technology at Kongu Engineering College, Perundurai, in April-May 2012.

\section{Materials and methods}

Effluent and characteristics

The egg processing effluent used in this study was obtained from an egg processing plant located in Erode, Tamil Nadu, India, and stored in airtight plastic cans at $4{ }^{\circ} \mathrm{C}$ to prevent natural degradation until it was used. The characteristics of egg processing effluent were as follows: $\mathrm{pH}, 7.34-7.95$; COD, 3,200-4,300 mg/l; BOD $5,1,800-2,250 \mathrm{mg} / \mathrm{l}$; total suspended solids, 1,050-1,280 mg/l; turbidity, 950-1,100 NTU; and conductivity, $0.455-0.614 \mathrm{mS} / \mathrm{cm}$.

Experimental setup and procedure

A laboratory glass beaker of $500 \mathrm{ml}$ was used for the electrocoagulation experiments (Sridhar et al. 2011). The electrodes used in the electrocoagulation system were made of aluminum (Al) having a surface area of $30 \mathrm{~cm}^{2}$. The area of electrode exposed for the electrolysis was fixed to be $25 \mathrm{~cm}^{2}$, and the remaining area was prevented from exposure with lacquer. The anode and cathode were positioned vertically and parallel to each other. The spacing between two electrodes in electrocoagulation process was varied in the range of $1-4 \mathrm{~cm}$. Bottom of the electrodes was kept $1 \mathrm{~cm}$ above the bottom of the reactor to allow easy stirring. Magnetic stirrer was used to agitate the solution. The current density was maintained constant by means of a precision digital direct current power supply $(0-30 \mathrm{~V}, 0-2 \mathrm{~A})$. All the electrocoagulation runs were conducted at room temperature. The impurities on the surfaces of electrodes were removed by dipping in $\mathrm{HCl}$ solution $(15 \% \mathrm{~W} / \mathrm{V})$ for 1-2 min. In each run, $300 \mathrm{ml}$ of egg processing effluent was placed into the electrocoagulation reactor. The current density was adjusted to a desired value, and the run was started. At the end of the run, the solution was filtered and the electrodes were washed thoroughly with distilled water to remove any solid residues on the surfaces, dried and used again. The filtered samples were analyzed for turbidity, COD and $\mathrm{BOD}_{5}$. 
Analytical procedures

The chemical oxygen demand and biochemical oxygen demand analysis were carried out by procedures described in standard methods (Greenberg et al. 1995). The turbidity (NTU) of samples was analyzed using Elico CL52D turbidity meter. The $\mathrm{pH}$ was measured using Elico LI120 model $\mathrm{pH}$ meter, and the conductivity was determined by Elico CM180 model conductivity meter.

\section{Electrical energy consumption}

The electrical energy consumption is very important economical parameter in electrocoagulation process. The electrical energy consumption was calculated using the following equation (Sridhar et al. 2011).

$\mathrm{E}=\frac{\mathrm{VIt}}{\mathrm{V}_{\mathrm{s}}}$

where $\mathrm{E}$ is the electrical energy $\left(\mathrm{kWh} / \mathrm{m}^{3}\right), \mathrm{V}$ is the cell voltage in volt $(\mathrm{V}), \mathrm{I}$ is the current in ampere $(\mathrm{A}), \mathrm{V}_{\mathrm{s}}$ is the volume of solution (l) and $t$ is the time of electrocoagulation process $(\mathrm{h})$.

\section{Results and discussion}

The effects of parameters

In the runs, the effects of parameters such as electrode distance, stirring speed, electrolyte concentration, $\mathrm{pH}$, current density and electrolysis time were investigated for percentage turbidity, $\mathrm{COD}$ and $\mathrm{BOD}_{5}$ removal.

\section{Effect of electrode distance}

Experiments were carried out by varying the electrode distance between 1 and $4 \mathrm{~cm}$, and the observations are given in Fig. 1a-c. From the figures, it is observed that the percentage removal of turbidity, $\mathrm{COD}$ and $\mathrm{BOD}_{5}$ increases with increasing electrode distance. The results indicate that when the inter-electrode distance is increased from 1 to $3 \mathrm{~cm}$, the removal of turbidity, $\mathrm{COD}$ and $\mathrm{BOD}_{5}$ increased by about 13,12 and $12 \%$, respectively, after $30 \mathrm{~min}$ of electrolysis time. A further increase in the distance beyond $3 \mathrm{~cm}$ decreased the percentage turbidity, $\mathrm{COD}$ and $\mathrm{BOD}_{5}$ removal due to the less interaction of ions with hydroxide polymers (Modirshahla et al. 2007). The removal efficiency is lower for 1-2-cm electrode distance than $3 \mathrm{~cm}$ because the gap between anode and cathode is too closed, and solid and fluid transfer was obstructed. The accumulated solid particles and bubbles between the anodes and the cathodes caused a consequent higher electrical resistance. The effect of inter-electrode distance on energy consumption is shown in Fig. 1d. From the figure, it is observed that the energy consumption increases with increasing electrode distance. The energy consumption is varied from 13.41 to $18.91 \mathrm{kWh} / \mathrm{m}^{3}$ at $30 \mathrm{~min}$ of electrolysis for $1-4-\mathrm{cm}$ electrode distance. The results suggest that the $3-\mathrm{cm}$ electrode distance can provide more economical operation.

\section{Effect of stirring speed}

The mixing is an important operating factor influencing the performance of electrocoagulation process. To examine its effect on the treatment of egg processing effluent, the stirring speed was varied in the range of 50-200 rpm. As shown in Fig. 2a-c, the percentage turbidity, $\mathrm{COD}$ and $\mathrm{BOD}_{5}$ removal increase by about 18 , 16 and $17 \%$, after $30 \mathrm{~min}$ of electrolysis time when the stirring speed was increased from 50 to $150 \mathrm{rpm}$. This confirms the fact that the removal efficiency is diffusion controlled, and the increase in stirring speed leads to increase in the intensity of turbulence and reduces the diffusion layer thickness at the electrode surface and improves the mixing conditions in the electrolyte bulk (Bouhezila et al. 2011; El-Ashtoukhy et al. 2009). No significant increase in turbidity, $\mathrm{COD}$ and $\mathrm{BOD}_{5}$ removal was observed by increasing stirring speed beyond $150 \mathrm{rpm}$. The effect of stirring speed (rpm) on energy consumption is shown in Fig. 2d. From the figure, it is found that the energy consumption decreases with increasing stirring speed because mainly it increases the intensity of turbulence and reduces the diffusion layer thickness at the electrode surface. But the energy consumption increases with increasing electrolysis time. The energy consumption was varied from 22.99 to $14.85 \mathrm{kWh} / \mathrm{m}^{3}$ at $30 \mathrm{~min}$ of electrolysis for $50-200 \mathrm{rpm}$ rotational speed. The result suggests that the stirring speed $150 \mathrm{rpm}$ can provide more economical operation because no significant reduction in $\mathrm{COD}$ and $\mathrm{BOD}_{5}$ when mixing speed beyond $150 \mathrm{rpm}$.

\section{Effect of electrolyte $(\mathrm{NaCl})$ concentration}

In general, the electrolytes are used to obtain the conductivity in electrocoagulation process. Solution conductivity affects the current efficiency, cell voltage and consumption of electrical energy in electrolytic cells. In this work, the conductivity of egg processing effluent was adjusted to the desired level by adding an appropriate amount of $\mathrm{NaCl}$ (Kobya and Delipinar 2008). The effect of $\mathrm{NaCl}$ concentration on turbidity removal efficiency is shown in Fig. 3a. Turbidity removal increased from 73 to $96 \%$ as $\mathrm{NaCl}$ concentration increased from 0.5 to $2.5 \mathrm{~g} / 1$. The increase in 
Fig. 1 Effect of electrode distance on, a percentage turbidity removal, b percentage COD removal, $\mathbf{c}$ percentage $\mathrm{BOD}_{5}$ removal and $\mathbf{d}$ energy consumption $(\mathrm{pH}=6$, current density $=20 \mathrm{~mA} / \mathrm{cm}^{2}$, $\mathrm{rpm}=150$ and $\mathrm{NaCl}=1.5$ $\mathrm{gm} / \mathrm{l})$

Fig. 2 Effect of rotational speed (rpm) on a percentage turbidity removal, $\mathbf{b}$ percentage COD removal, $\mathbf{c}$ percentage $\mathrm{BOD}_{5}$ removal and $\mathbf{d}$ energy consumption $(\mathrm{pH}=6$, current density $=20 \mathrm{~mA} / \mathrm{cm}^{2}$,

$\mathrm{NaCl}=1.5 \mathrm{~g} / \mathrm{l}$ and electrode distance $=3 \mathrm{~cm}$ )
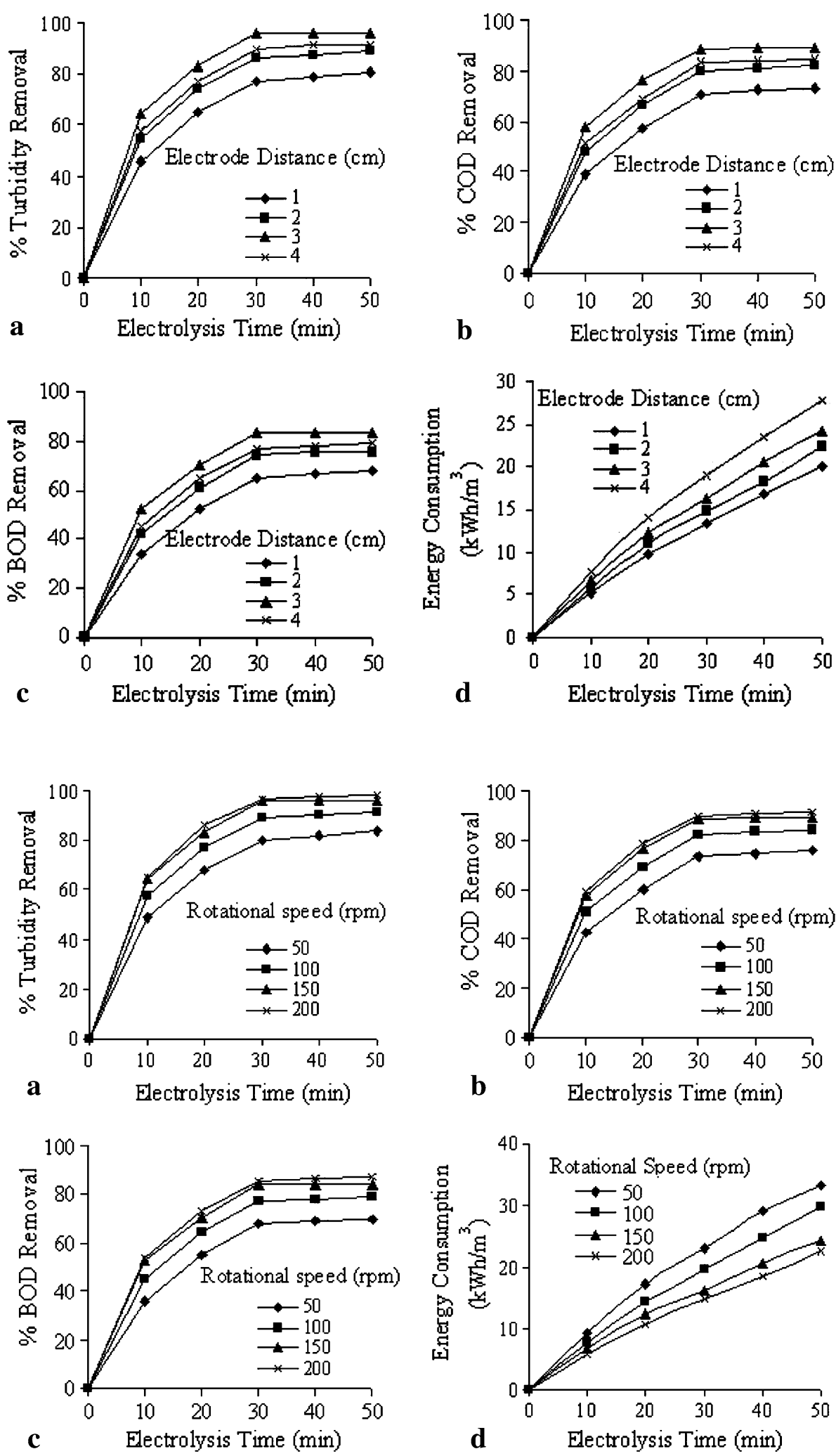

the removal efficiency may be attributed to a change in the ionic strength due to the changing conductivity of aqueous medium. The higher ionic strength will generally cause an increase in current density in the same cell voltage or, equivalently, the cell voltage decreases with increasing effluent conductivity at constant current density. Also, with 
the addition of $\mathrm{NaCl}$ to the medium, following reactions take place in the effluent (Chen 2004).

$$
\begin{aligned}
& 2 \mathrm{Cl}^{-} \rightarrow \mathrm{Cl}_{2}+2 e^{-} \\
& \mathrm{Cl}_{2}+\mathrm{H}_{2} \mathrm{O} \rightarrow \mathrm{HOCl}+\mathrm{Cl}^{-}+\mathrm{H}^{+} \\
& \mathrm{HOCl} \rightarrow \mathrm{OCl}^{-}+\mathrm{H}^{+}
\end{aligned}
$$

As shown in above reactions, when sodium chlorides are added into the solutions, the products discharged from anode are $\mathrm{Cl}_{2}$ and $\mathrm{OCl}^{-}$. The $\mathrm{OCl}^{-}$itself is a strong oxidant, which capable of oxidizing organic molecules present in effluent and hence turbidity removal increases. Therefore, addition of $\mathrm{NaCl}$ not only increases the conductivity but also contributes strong oxidizing agents (Sridhar et al. 2011). The presence of $\mathrm{NaCl}$ has a considerable effect on the percentage $\mathrm{COD}$ and $\mathrm{BOD}_{5}$ removal up to $1.5 \mathrm{~g} / \mathrm{l}$, beyond that there is no significant reduction in COD and $\mathrm{BOD}_{5}$ (Fig. 3b, c). The effect of electrolyte concentration on energy consumption for $\mathrm{Al}$ electrode is shown in Fig. 3d. The energy consumption decreased with increasing concentration of supporting electrolyte because the potential decreased under constant current density. The energy consumption was varied from 21.91 to $14.74 \mathrm{kWh} /$ $\mathrm{m}^{3}$ at $30 \mathrm{~min}$ of electrolysis for $0.5-2.5 \mathrm{~g} / \mathrm{l} \mathrm{NaCl}$. According to the results, high removal percentage with low cell voltages and low energy consumption was obtained with $\mathrm{NaCl}$ concentration of around $1.5 \mathrm{~g} / \mathrm{l}$.
Effect of $\mathrm{pH}$

The influent effluent $\mathrm{pH}$ is one of the important factors which affect the performance of electrocoagulation process. To evaluate this effect, a series of experiments were performed. The effect of $\mathrm{pH}$ on the turbidity, COD and $\mathrm{BOD}_{5}$ removal was examined at 4, 5, 6, 7 and $8 \mathrm{pH}$. From the Fig. $4 \mathrm{a}-\mathrm{c}$, it is observed that the percentage of turbidity, $\mathrm{COD}$ and $\mathrm{BOD}_{5}$ removal increases with increasing $\mathrm{pH}$ up to 6 and then decreased. The extent of hydrolysis depends upon total pollutant concentration and $\mathrm{pH}$, as well as the amount of other species present in solution. At lower $\mathrm{pH}$ less than 6 , the protons in the solution are reduced to $\mathrm{H}_{2}$ at the cathode, and the same proportion of hydroxide ions could not be produced, which leads to the formation of $\mathrm{Al}(\mathrm{OH})^{2+}$ and $\mathrm{Al}(\mathrm{OH})_{2}^{+}$, and hence, $\mathrm{COD}$ and $\mathrm{BOD}_{5}$ reduction was found to be less (Mollah et al. 2001). When is $\mathrm{pH}$ 6-6.5, there is a formation of $\mathrm{Al}(\mathrm{III})$ species in the form of $\mathrm{Al}(\mathrm{OH})_{3(\mathrm{~s})}$ which increases the $\mathrm{BOD}_{5}$ and $\mathrm{COD}$ removal efficiency. $\mathrm{Al}(\mathrm{OH})_{4}^{-}$forms at the higher $\mathrm{pH}$, which is dissolving nature in the effluent and does not form flocks, and hence, there is no reduction in turbidity, COD and $\mathrm{BOD}_{5}$ (Zaied and Bellakhal 2009). The relationship between the energy consumption and $\mathrm{pH}$ is shown in Fig. 4d. The energy consumption increased with increasing the $\mathrm{pH}$ values. The minimum and maximum energy consumption was observed at $\mathrm{pH} 4$ and 8 , respectively. The
Fig. 3 Effect of $\mathrm{NaCl}$ concentration on a percentage turbidity removal, b percentage COD removal, $\mathbf{c}$ percentage $\mathrm{BOD}_{5}$ removal and d energy consumption $(\mathrm{pH}=6$, current density $=20 \mathrm{~mA} / \mathrm{cm}^{2}$, $\mathrm{rpm}=150$ and electrode distance $=3 \mathrm{~cm}$ )
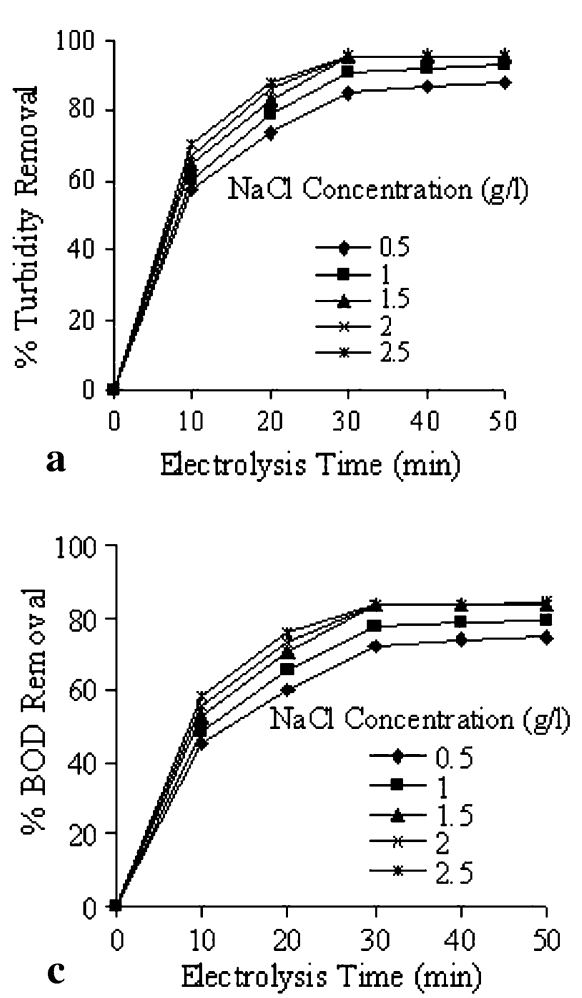
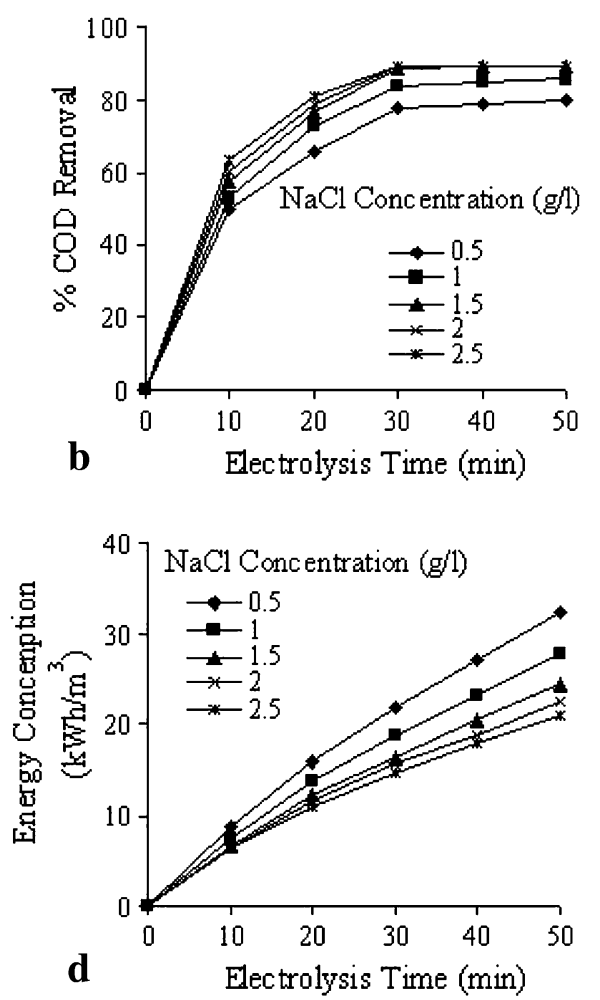
energy consumption is varied from 14.41 to $19.24 \mathrm{kWh} / \mathrm{m}^{3}$ at $30 \mathrm{~min}$ of electrolysis for the $\mathrm{pH}$ range of 4-8.

Effect of electrolysis time and current density

From the Fig. 5a-c, it is observed that the turbidity, COD and $\mathrm{BOD}_{5}$ removal efficiency increases with increasing electrolysis time. After $30 \mathrm{~min}$ of electrolysis turbidity, $\mathrm{COD}$ and $\mathrm{BOD}_{5}$ removal efficiency reached a maximum at all current density except for $10 \mathrm{~mA} / \mathrm{cm}^{2}$.

The current density is the most important parameter in all electrocoagulation process. The current density determines not only the coagulant dosage rate but also the bubble production rate, size and the flocs growth, and they have strong influence on treatment efficiency of the electrocoagulation process. Fig. 5a-c illustrate that the turbidity, $\mathrm{COD}$ and $\mathrm{BOD}_{5}$ removal efficiency increased from 84 to $96 \%$ by increasing the current density from 10 to $30 \mathrm{~mA} / \mathrm{cm}^{2}$ for $30 \mathrm{~min}$ electrolysis time. This is mainly due to direct and indirect oxidation. When sufficient voltage is developed across the electrodes, direct oxidation takes place near the anode, due to the release of electrons by the organic compounds in order to maintain the flow of current, whereas indirect oxidation occurs due to the strong oxidants that form during the reaction. Here, the $\mathrm{Cl}^{-}$can be the principal charged species which carry the current in the solution. If $\mathrm{Cl}^{-}$ carries the current, then $\mathrm{Cl}_{2}$ gas is produced at the anodes which rapidly hydrolyze to form hypochlorous acid, which is a strong oxidant, and has the ability to oxidize the organic compounds effectively (Kobya and Delipinar 2008; Adhoum et al. 2004). The removal of turbidity, $\mathrm{COD}$ and $\mathrm{BOD}_{5}$ was increased with increasing current density up to $30 \mathrm{~min}$. After $30 \mathrm{~min}$, increasing current density beyond $20 \mathrm{~mA} / \mathrm{cm}^{2}$ did not show any significant improvement on the percentage of turbidity, COD and $\mathrm{BOD}_{5}$ removal. The effect of current density on energy consumption is shown in Fig. 5d. The energy consumption increased with increasing current density due to increase in ion production on the anode and cathode. The energy consumption is varied from 7.91 to $27.16 \mathrm{kWh} / \mathrm{m}^{3}$ in the current density range of $10-30 \mathrm{~mA} / \mathrm{cm}^{2}$.

\section{Effect of parameters on operating cost}

The operating cost is very important economical parameter in electrocoagulation process. The operating cost involves costs of chemicals, electrodes and energy consumptions as well as labor, maintenance, sludge disposal and fixed costs. The energy, electrode and chemical costs were taken into account as major cost items in the calculation of operating cost (Bayramoglu et al. 2004; Sridhar et al. 2011).

$$
\begin{aligned}
\text { Operating cost }\left(\mathrm{US} \$ / \mathrm{m}^{3}\right)= & a C_{\text {energy }}+b C_{\text {electrode }} \\
& +c C_{\text {chemicals }}
\end{aligned}
$$

where $\mathrm{C}_{\text {energy }}$ is the electrode and magnetic stirrer energy consumption $\left(\mathrm{kWh} / \mathrm{m}^{3}\right), \mathrm{C}_{\text {electrode }}$ is the electrode consumption $\left(\mathrm{kg} / \mathrm{m}^{3}\right)$ and $\mathrm{C}_{\text {chemicals }}$ is the chemical
Fig. 4 Effect of $\mathrm{pH}$ on percentage a percentage turbidity removal b percentage COD removal and $\mathbf{c} \mathrm{BOD}_{5}$ removal and $\mathbf{d}$ energy consumption $(\mathrm{rpm}=150$, current density $=20 \mathrm{~mA} / \mathrm{cm}^{2}$, $\mathrm{NaCl}=1.5 \mathrm{~g} / \mathrm{l}$ and electrode distance $=3 \mathrm{~cm}$ )
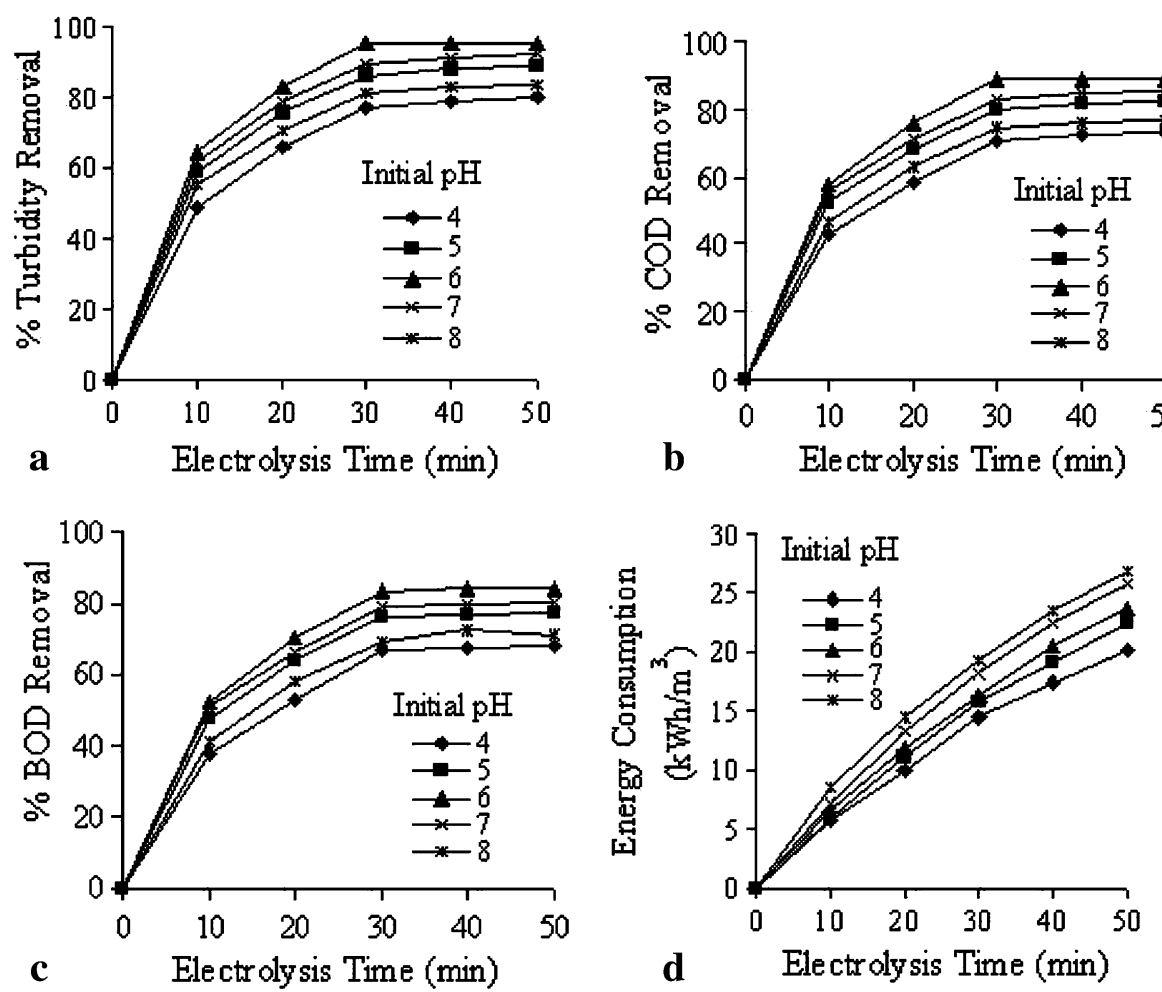
Fig. 5 Effect of current density on a percentage turbidity removal, b percentage COD removal, c percentage $\mathrm{BOD}_{5}$ removal and $\mathbf{d}$ energy consumption $(\mathrm{rpm}=150$, $\mathrm{pH}=6, \mathrm{NaCl}=1.5 \mathrm{~g} / \mathrm{l}$ and electrode distance $=3 \mathrm{~cm}$ )
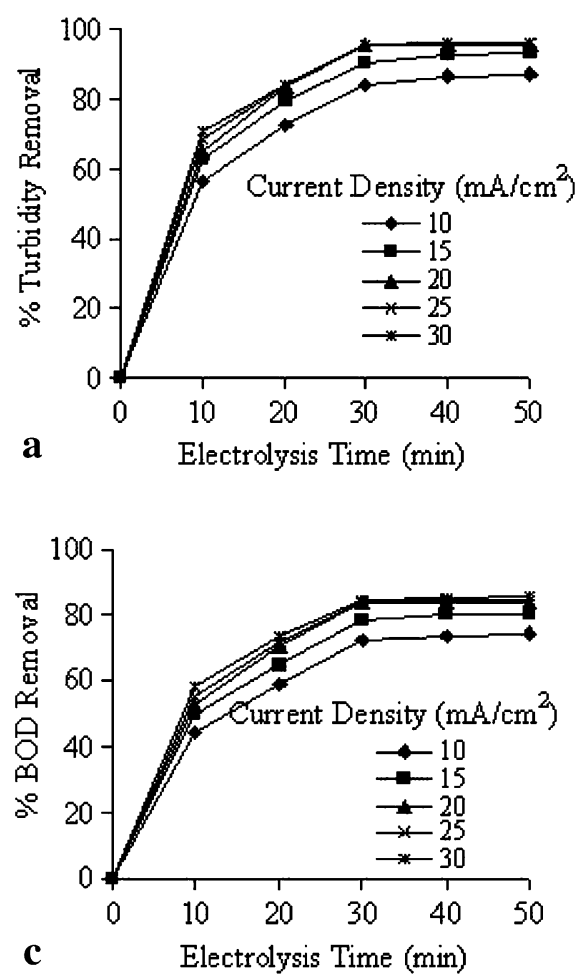
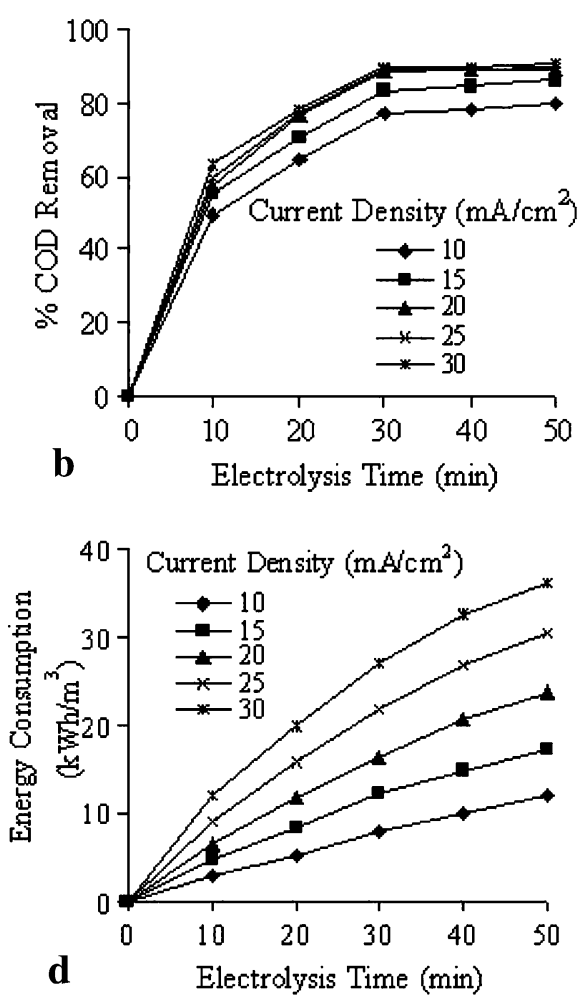

consumption $\left(\mathrm{kg} / \mathrm{m}^{3}\right)$. Unit prices $\mathrm{a}, \mathrm{b}$ and $\mathrm{c}$ given for the price at first quarter of 2012, India, are as follows: (a) electrical energy price $0.085 \mathrm{US} \$ / \mathrm{kWh}$, (b) electrode material (Al) price 2.23 US $\$ / \mathrm{kg}$ and (c) electrolyte $(\mathrm{NaCl})$ price 0.043 US $\$ / \mathrm{kg}$.

The operating cost increased with increasing electrode distance, $\mathrm{pH}$ and current density and decreased with increasing stirrer speed and electrolyte concentration. The operating costs were determined as 2.46-2.92, 2.54-2.95, $1.36-4.25,3.27-2.58$ and $3.14-2.61 \$ / \mathrm{m}^{3}$ at electrode distance of $1-4 \mathrm{~cm}, \mathrm{pH}$ of $4-8$, current density of $10-30 \mathrm{~mA} / \mathrm{cm}^{2}$, stirrer speed of $50-200 \mathrm{rpm}$ and electrolyte concentration of $0.5-2.5 \mathrm{~g} / 1$, at $30 \mathrm{~min}$ of electrolysis, respectively. Under optimal operating condition such as $20 \mathrm{~mA} / \mathrm{cm}^{2}$ current density, $\mathrm{pH}$ of $6,1.5 \mathrm{~g} / 1 \mathrm{NaCl}$, $150 \mathrm{rpm}, 3-\mathrm{cm}$ electrode distance and $30 \mathrm{~min}$ of electrolysis, the operating cost is found to be $2.7 \mathrm{US} \$ / \mathrm{m}^{3}$.

\section{Development of model}

\section{Experimental design and procedure}

In this study, the Box-Behnken design with four factors at three levels was applied using Stat Ease Design-Expert 8.0.4 with the limits of the independent variables. Each independent variable was coded at three levels between -1 and +1 in the ranges determined by the preliminary experiments. Table 1 gives the parameters and the operating ranges covered. A total of 29 experiments, including five center points, were employed to evaluate the individual and interactive effects of the four main independent parameters on the turbidity, $\mathrm{COD}, \mathrm{BOD}_{5}$ removal efficiency and energy consumption. Percentage turbidity, COD and $\mathrm{BOD}_{5}$ removal and energy consumption have been taken as a response $(Y)$ of the system, while four process parameters, namely current density $(j): 10-30 \mathrm{~mA} / \mathrm{cm}^{2} ; \mathrm{pH}$ $\left(\mathrm{pH}_{0}\right): 4-8$; electrolyte concentration $(c): 0.5-2.5 \mathrm{~g} / \mathrm{l}$; and electrolysis time $(t): 10-50 \mathrm{~min}$, have been taken as input parameters. Experimental conditions and corresponding results (responses) are present in Table 2. The performance of the process was evaluated by analyzing the responses. A non-linear regression method was used to fit the secondorder polynomial equation to the experimental data (Prakash Maran et al. 2013a; Sridhar et al. 2011). The statistical significance of the models was justified through analysis of variance (ANOVA) for polynomial model. The quality of the fit polynomial model was also expressed with the coefficient of determination $R^{2}$.

\section{Statistical analysis}

Experiments were performed to study the effect of $j, \mathrm{pH}_{0}$, $c$ and $t$ on the turbidity removal, COD removal, $\mathrm{BOD}_{5}$ removal and energy consumption. The results of the $Y$ (response) of turbidity removal, $\mathrm{COD}$ removal, $\mathrm{BOD}_{5}$ removal and energy consumption were measured according to design matrix, and the measured responses are listed in Table 2. In order to quantify the curvature effects, the data 
Table 1 Process parameters and their levels for electrocoagulation treatment

\begin{tabular}{|c|c|c|c|c|}
\hline \multirow[t]{2}{*}{ Variable, unit } & \multirow{2}{*}{$\begin{array}{l}\text { Factors } \\
X\end{array}$} & \multicolumn{3}{|c|}{ Level } \\
\hline & & -1 & 0 & +1 \\
\hline Current density, $j\left(\mathrm{~mA} / \mathrm{cm}^{2}\right)$ & $X_{1}$ & 10 & 20 & 30 \\
\hline Initial $\mathrm{pH}, \mathrm{pH}_{\mathrm{o}}$ & $X_{2}$ & 4 & 6 & 8 \\
\hline Electrolyte concentration, $c(\mathrm{~g} / \mathrm{l})$ & $X_{3}$ & 0.5 & 1.5 & 2.5 \\
\hline Electrolysis time, $t(\min )$ & $X_{4}$ & 10 & 30 & 50 \\
\hline
\end{tabular}

from the experimental results were fitted to four higher degree polynomial equations viz., linear, two factor interaction (2F1), quadratic and cubic models. Two different tests, namely the sequential model sum of squares and model summary statistics were employed to decide about the adequacy of various models to represent turbidity removal, $\mathrm{COD}$ removal, $\mathrm{BOD}_{5}$ removal and energy consumption, and the results of these tests are given in Table 3. Cubic model was found to be aliased and cannot be used for further modeling of experimental data. Though the $p$ values were in the acceptable range of both linear and two factor interaction (2F1) models, the adjusted $R^{2}$ and predicted $R^{2}$ values were found to be low (refer Table 3); however, and hence, these two models were eliminated. On the other hand, the quadratic model exhibited low $p$ values $(<0.0001)$ and high adjusted $R^{2}$ and predicted $R^{2}$ values and was chosen for further analyses.

\section{Development of regression model equation and validation of the model}

The adequacy of the model was evaluated through ANOVA (analysis of variance) (Sridhar et al. 2011). The ANOVA

Table 2 Box-Behnken design with observed and predicted responses

\begin{tabular}{|c|c|c|c|c|c|c|c|c|c|c|c|c|}
\hline \multirow[t]{2}{*}{ Run order } & \multirow[t]{2}{*}{$j\left(X_{1}\right)$} & \multirow[t]{2}{*}{$\mathrm{pH}\left(X_{2}\right)$} & \multirow[t]{2}{*}{$c\left(X_{3}\right)$} & \multirow[t]{2}{*}{$t\left(X_{4}\right)$} & \multicolumn{2}{|c|}{$\%$ Turbidity removal } & \multicolumn{2}{|c|}{$\%$ COD removal } & \multicolumn{2}{|c|}{$\% \mathrm{BOD}_{5}$ removal } & \multicolumn{2}{|c|}{ Energy consumption $\left(\mathrm{kWh} / \mathrm{m}^{3}\right)$} \\
\hline & & & & & $Y_{\exp }$ & $Y_{\text {pre }}$ & $Y_{\exp }$ & $Y_{\text {pre }}$ & $Y_{\exp }$ & $Y_{\text {pre }}$ & $Y_{\exp }$ & $Y_{\text {pre }}$ \\
\hline 1 & 20 & 8 & 1.5 & 50 & 84.00 & 83.34 & 76.50 & 76.10 & 71.00 & 70.48 & 26.79 & 27.77 \\
\hline 2 & 20 & 8 & 1.5 & 10 & 55.00 & 55.65 & 46.50 & 47.40 & 41.00 & 41.77 & 8.47 & 8.37 \\
\hline 3 & 30 & 6 & 2.5 & 30 & 96.13 & 97.31 & 89.14 & 90.61 & 84.12 & 85.71 & 23.91 & 23.45 \\
\hline 4 & 20 & 6 & 0.5 & 50 & 87.75 & 87.83 & 79.88 & 80.16 & 74.66 & 75.05 & 32.34 & 31.79 \\
\hline 5 & 20 & 6 & 2.5 & 10 & 70.71 & 70.57 & 63.03 & 62.88 & 58.44 & 58.28 & 7.70 & 7.81 \\
\hline 6 & 20 & 4 & 0.5 & 30 & 68.44 & 68.98 & 61.17 & 61.82 & 56.03 & 56.70 & 20.07 & 19.77 \\
\hline 7 & 10 & 6 & 1.5 & 50 & 87.32 & 87.44 & 79.94 & 79.66 & 74.38 & 74.17 & 11.06 & 10.84 \\
\hline 8 & 20 & 6 & 1.5 & 30 & 95.56 & 95.56 & 88.65 & 88.65 & 83.66 & 83.66 & 16.24 & 16.24 \\
\hline 9 & 30 & 8 & 1.5 & 30 & 86.56 & 85.97 & 78.16 & 77.40 & 72.33 & 71.73 & 32.16 & 31.79 \\
\hline 10 & 10 & 4 & 1.5 & 30 & 68.94 & 69.49 & 60.72 & 61.63 & 55.52 & 56.35 & 7.67 & 7.78 \\
\hline 11 & 20 & 4 & 1.5 & 10 & 49.10 & 50.03 & 42.60 & 43.39 & 37.77 & 38.64 & 5.20 & 5.19 \\
\hline 12 & 10 & 6 & 2.5 & 30 & 89.00 & 89.05 & 80.90 & 80.84 & 75.42 & 75.34 & 11.12 & 11.27 \\
\hline 13 & 30 & 6 & 1.5 & 10 & 70.95 & 70.61 & 63.00 & 62.73 & 58.09 & 57.71 & 12.05 & 12.27 \\
\hline 14 & 20 & 4 & 2.5 & 30 & 81.13 & 80.16 & 74.57 & 73.35 & 69.17 & 67.89 & 17.41 & 16.66 \\
\hline 15 & 10 & 6 & 0.5 & 30 & 75.00 & 74.08 & 67.64 & 66.55 & 62.55 & 61.30 & 11.12 & 11.43 \\
\hline 16 & 20 & 6 & 1.5 & 30 & 95.56 & 95.56 & 88.65 & 88.65 & 83.66 & 83.66 & 16.24 & 16.24 \\
\hline 17 & 20 & 6 & 2.5 & 50 & 96.02 & 96.65 & 89.08 & 90.23 & 84.14 & 85.30 & 20.95 & 20.60 \\
\hline 18 & 20 & 4 & 1.5 & 50 & 80.04 & 79.65 & 73.48 & 72.97 & 68.00 & 67.57 & 20.12 & 20.36 \\
\hline 19 & 20 & 6 & 0.5 & 10 & 57.27 & 56.60 & 50.23 & 49.23 & 45.36 & 44.43 & 9.80 & 10.01 \\
\hline 20 & 10 & 8 & 1.5 & 30 & 71.54 & 72.16 & 63.66 & 64.44 & 57.11 & 57.99 & 10.24 & 10.66 \\
\hline 21 & 20 & 6 & 1.5 & 30 & 95.56 & 95.56 & 88.65 & 88.65 & 83.66 & 83.66 & 16.24 & 16.24 \\
\hline 22 & 20 & 8 & 2.5 & 30 & 85.79 & 85.03 & 78.45 & 77.25 & 73.00 & 71.76 & 19.07 & 18.37 \\
\hline 23 & 10 & 6 & 1.5 & 10 & 56.66 & 56.23 & 49.20 & 48.92 & 44.30 & 44.10 & 1.00 & 0.99 \\
\hline 24 & 30 & 6 & 1.5 & 50 & 96.50 & 96.71 & 90.52 & 90.26 & 85.66 & 85.28 & 36.09 & 36.99 \\
\hline 25 & 20 & 6 & 1.5 & 30 & 95.56 & 95.56 & 88.65 & 88.65 & 83.66 & 83.66 & 16.24 & 16.24 \\
\hline 26 & 20 & 8 & 0.5 & 30 & 72.68 & 73.42 & 64.39 & 65.06 & 58.15 & 58.86 & 28.91 & 28.65 \\
\hline 27 & 20 & 6 & 1.5 & 30 & 95.56 & 95.56 & 88.65 & 88.65 & 83.66 & 83.66 & 16.24 & 16.24 \\
\hline 28 & 30 & 4 & 1.5 & 30 & 80.00 & 79.33 & 73.71 & 73.08 & 68.00 & 67.34 & 23.66 & 24.08 \\
\hline 29 & 30 & 6 & 0.5 & 30 & 89.27 & 89.48 & 80.74 & 81.19 & 75.24 & 75.65 & 37.41 & 36.69 \\
\hline
\end{tabular}


Table 3 Adequacy of the models tested for turbidity, COD, BOD $_{5}$ removal and energy consumption

\begin{tabular}{|c|c|c|c|c|c|c|c|c|}
\hline Source & Sum of squares & \multicolumn{2}{|c|}{ Degree of freedom } & \multicolumn{2}{|c|}{ Mean square } & $F$ value & Prob $>F$ & Remark \\
\hline \multicolumn{9}{|c|}{ Sequential model sum of squares for turbidity removal } \\
\hline Mean & $1.878 \mathrm{E}+005$ & 1 & & \multicolumn{3}{|c|}{$1.878 \mathrm{E}+005$} & & \\
\hline Linear & $3,337.60$ & 4 & & \multicolumn{2}{|c|}{834.40} & 8.92 & 0.0001 & \\
\hline $2 \mathrm{~F} 1$ & 30.85 & 6 & & \multicolumn{2}{|c|}{5.14} & 0.042 & 0.9996 & \\
\hline Quadratic & $2,205.80$ & 4 & & \multicolumn{2}{|c|}{551.45} & 837.72 & $<0.0001$ & Suggested \\
\hline Cube & 8.98 & 8 & & \multicolumn{2}{|c|}{1.12} & 28.75 & 0.0003 & Aliased \\
\hline Residual & 0.23 & 6 & & \multicolumn{3}{|c|}{0.039} & & \\
\hline \multicolumn{9}{|c|}{ Sequential model sum of squares for COD removal } \\
\hline Mean & $1.55 \mathrm{E}+005$ & 1 & & \multicolumn{3}{|c|}{$1.55 \mathrm{E}+005$} & & \\
\hline Linear & $3,453.83$ & 4 & & \multicolumn{2}{|c|}{863.46} & 9.10 & 0.0001 & \\
\hline $2 \mathrm{~F} 1$ & 12.56 & 6 & & \multicolumn{2}{|c|}{2.09} & 0.017 & 1.0000 & \\
\hline Quadratic & $2,250.96$ & 4 & & \multicolumn{2}{|c|}{562.74} & 548.11 & $<0.0001$ & Suggested \\
\hline Cube & 13.45 & 8 & & \multicolumn{2}{|c|}{1.68} & 10.86 & 0.0046 & Aliased \\
\hline Residual & 0.93 & 6 & & \multicolumn{3}{|c|}{0.15} & & \\
\hline \multicolumn{9}{|c|}{ Sequential model sum of squares for $\mathrm{BOD}_{5}$ removal } \\
\hline Mean & $1.335 \mathrm{E}+005$ & 1 & & \multicolumn{3}{|c|}{$1.335 \mathrm{E}+005$} & & \\
\hline Linear & $3,412.68$ & 4 & & \multicolumn{2}{|c|}{853.17} & 8.74 & 0.0002 & \\
\hline $2 \mathrm{~F} 1$ & 11.40 & 6 & & \multicolumn{2}{|c|}{1.90} & 0.015 & 1.0000 & \\
\hline Quadratic & $2,317.25$ & 4 & & & & 532.83 & $<0.0001$ & Suggested \\
\hline Cube & 14.22 & 8 & & & & 10.66 & 0.0049 & Aliased \\
\hline Residual & 1.00 & 6 & & & & & & \\
\hline Sequential $n$ & um of squares for & rgy consu & & & & & & \\
\hline Mean & $9,138.61$ & 1 & & & & & & \\
\hline Linear & $2,165.66$ & 4 & & & & 44.46 & 0.0001 & \\
\hline $2 \mathrm{~F} 1$ & 141.39 & 6 & & & & 2.81 & 0.0413 & \\
\hline Quadratic & 134.31 & 4 & & & & 28.42 & $<0.0001$ & Suggested \\
\hline Cube & 13.04 & 8 & & & & 2.79 & 0.1141 & Aliased \\
\hline Residual & 3.51 & 6 & & & & & & \\
\hline Source & SD & $R^{2}$ & Adj & & & $R^{2}$ & PRESS & Remark \\
\hline Model sumn & atistics for turbidit & moval & & & & & & \\
\hline Linear & 9.67 & 0.5978 & 0.53 & & & & $2,956.33$ & \\
\hline $2 \mathrm{~F} 1$ & 11.09 & 0.6033 & 0.38 & & & & $4,794.02$ & \\
\hline Quadratic & 0.81 & 0.9983 & 0.99 & & & & 53.08 & Suggested \\
\hline Cubic & 0.20 & 1.0000 & 0.99 & & & & 33.74 & Aliased \\
\hline Model sumn & atistics for COD $r$ & val & & & & & & \\
\hline Linear & 9.74 & 0.6026 & 0.53 & & & & $2,973.19$ & \\
\hline $2 \mathrm{~F} 1$ & 11.22 & 0.6048 & 0.38 & & & & $4,809.66$ & \\
\hline Quadratic & 1.01 & 0.9975 & 0.99 & & & & 82.79 & Suggested \\
\hline Cubic & 0.39 & 0.9998 & 0.99 & & & & 133.71 & Aliased \\
\hline Model sumn & atistics for $\mathrm{BOD}_{5}$ & oval & & & & & & \\
\hline Linear & 9.88 & 0.5928 & 0.52 & & & & $3,055.22$ & \\
\hline $2 \mathrm{~F} 1$ & 11.38 & 0.5948 & 0.36 & & & & $4,935.42$ & \\
\hline Quadratic & 1.04 & 0.9974 & 0.99 & & & & 87.68 & Suggested \\
\hline Cubic & 0.41 & 0.9998 & 0.99 & & & & 144.08 & Aliased \\
\hline Model sumn & atistics for energy & sumption & & & & & & \\
\hline Linear & 3.49 & 0.8811 & 0.86 & & & & 452.29 & \\
\hline $2 \mathrm{~F} 1$ & 2.89 & 0.9386 & 0.90 & & & & 475.04 & \\
\hline Quadratic & 1.09 & 0.9933 & 0.98 & & & & 95.28 & Suggested \\
\hline Cubic & 0.76 & 0.9986 & 0.99 & & & & 504.84 & Aliased \\
\hline
\end{tabular}


Table 4 ANOVA results of the quadratic models for turbidity, COD, $\mathrm{BOD}_{5}$ removal and energy consumption

\begin{tabular}{|c|c|c|c|c|c|c|c|c|c|c|c|c|}
\hline \multirow[t]{2}{*}{ Factor } & \multicolumn{3}{|c|}{$\%$ Turbidity removal } & \multicolumn{3}{|c|}{ \% COD removal } & \multicolumn{3}{|c|}{$\% \mathrm{BOD}_{5}$ removal } & \multicolumn{3}{|c|}{ Energy consumption $\left(\mathrm{kWh} / \mathrm{m}^{3}\right)$} \\
\hline & $\begin{array}{l}\text { Coeff. of } \\
\text { the model }\end{array}$ & $F$ Value & $P$ Value & $\begin{array}{l}\text { Coeff. of } \\
\text { the model }\end{array}$ & $F$ Value & $P$ Value & $\begin{array}{l}\text { Coeff. of } \\
\text { the model }\end{array}$ & $F$ Value & $P$ Value & $\begin{array}{l}\text { Coeff. of } \\
\text { the model }\end{array}$ & $F$ Value & $P$ Value \\
\hline Model & 95.56 & 604.85 & $<0.0001$ & 88.65 & 397.76 & $<0.0001$ & 83.66 & 377.19 & $<0.0001$ & 16.24 & 147.59 & $<0.0001$ \\
\hline$X_{1}$ & 5.91 & 637.44 & $<0.0001$ & 6.10 & 435.15 & $<0.0001$ & 6.18 & 421.65 & $<0.0001$ & 9.36 & 889.12 & $<0.0001$ \\
\hline$X_{2}$ & 2.33 & 98.75 & $<0.0001$ & 1.78 & 37.21 & $<0.0001$ & 1.51 & 25.08 & 0.0002 & 2.65 & 71.22 & $<0.0001$ \\
\hline$X_{3}$ & 5.70 & 591.93 & $<0.0001$ & 5.93 & 410.78 & $<0.0001$ & 6.02 & 400.54 & $<0.0001$ & -3.35 & 113.95 & $<0.0001$ \\
\hline$X_{4}$ & 14.33 & $3,742.08$ & $<0.0001$ & 14.57 & $2,480.90$ & $<0.0001$ & 14.41 & $2,291.56$ & $<0.0001$ & 8.64 & 758.63 & $<0.0001$ \\
\hline$X_{1}^{2}$ & -4.12 & 167.33 & $<0.0001$ & -4.54 & 130.32 & $<0.0001$ & -4.80 & 137.58 & $<0.0001$ & 1.09 & 6.58 & 0.0224 \\
\hline$X_{2}^{2}$ & -14.70 & $2,130.62$ & $<0.0001$ & -14.97 & $1,415.91$ & $<0.0001$ & -15.50 & $1,434.18$ & $<0.0001$ & 1.25 & 8.55 & 0.0111 \\
\hline$X_{3}^{2}$ & -3.96 & 154.39 & $<0.0001$ & -4.31 & 117.32 & $<0.0001$ & -4.35 & 113.13 & $<0.0001$ & 3.38 & 62.58 & $<0.0001$ \\
\hline$X_{4}^{2}$ & -13.69 & $1,846.63$ & $<0.0001$ & -13.72 & $1,188.46$ & $<0.0001$ & -13.54 & $1,094.09$ & $<0.0001$ & -2.06 & 23.33 & 0.0003 \\
\hline$X_{1} \times X_{2}$ & 0.99 & 5.99 & 0.0282 & 0.38 & 0.56 & 0.4685 & 0.68 & 1.73 & 0.2100 & 1.21 & 4.94 & 0.0432 \\
\hline$X_{1} \times X_{3}$ & -1.79 & 19.36 & 0.0006 & -1.22 & 5.75 & 0.0310 & -1.00 & 3.64 & 0.0770 & -3.27 & 36.22 & $<0.0001$ \\
\hline$X_{1} \times X_{4}$ & -1.28 & 9.92 & 0.0071 & -0.80 & 2.51 & 0.1355 & -0.63 & 1.45 & 0.2487 & 3.72 & 46.73 & $<0.0001$ \\
\hline$X_{2} \times X_{3}$ & 0.11 & 0.067 & 0.7995 & 0.17 & 0.11 & 0.7495 & 0.43 & 0.67 & 0.4260 & -1.79 & 10.87 & 0.0053 \\
\hline$X_{2} \times X_{4}$ & -0.49 & 1.43 & 0.2517 & -0.22 & 0.19 & 0.6707 & -0.06 & 0.011 & 0.9175 & 1.06 & 3.77 & 0.0725 \\
\hline$X_{3} \times X_{4}$ & -1.29 & 10.11 & 0.0067 & -0.90 & 3.12 & 0.0991 & -0.90 & 2.98 & 0.1063 & -2.25 & 17.14 & 0.0010 \\
\hline
\end{tabular}

Fig. 6 Comparison of experimental and predicted a percentage turbidity removal, b percentage COD removal, c percentage $\mathrm{BOD}_{5}$ removal and d energy consumption by RSM

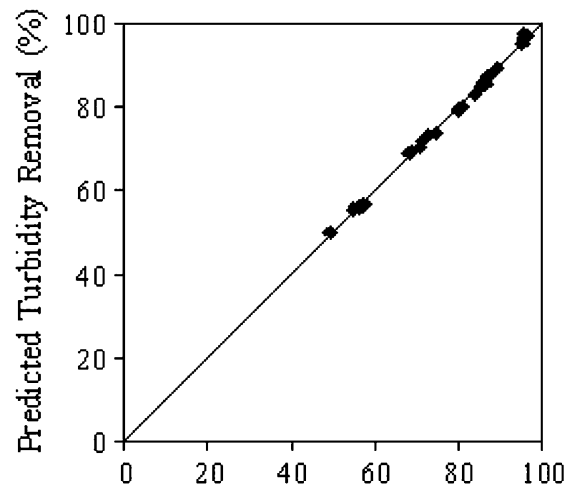

a Experimental Turbidity Removal (\%)

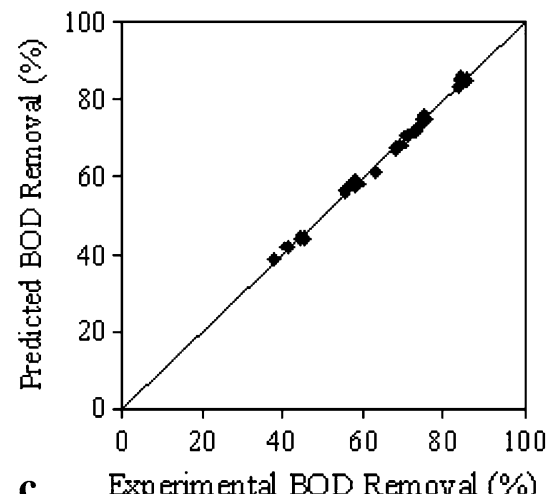

c Experimental BOD Removal (\%)

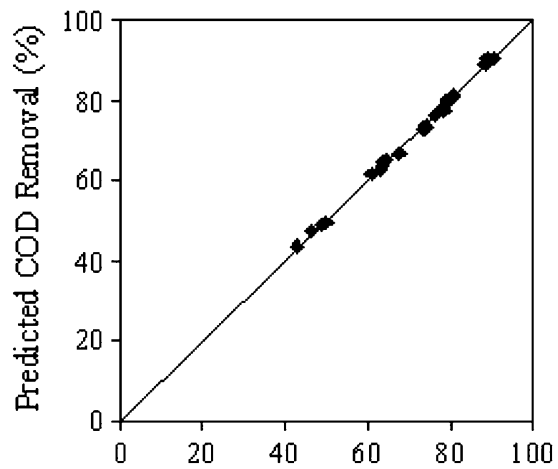

b Experimental COD Removal (\%)

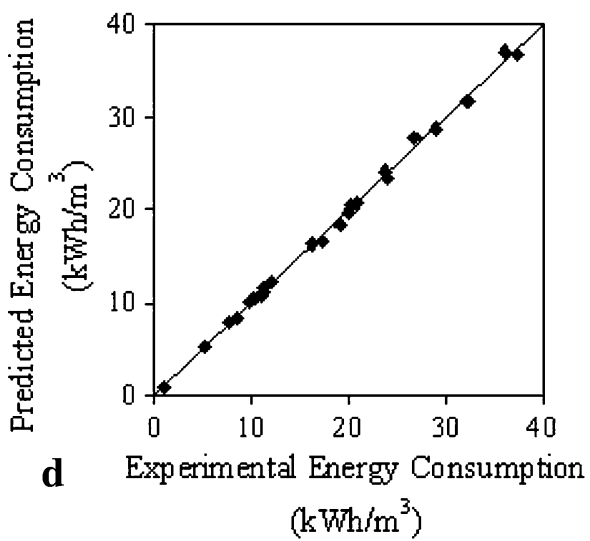

results for turbidity removal, $\mathrm{COD}$ removal, $\mathrm{BOD}_{5}$ removal and energy consumption are shown in Table 4. The large value of $F$ (604.85 for percentage turbidity removal, 397.76 for percentage COD removal, 377.19 for percentage $\mathrm{BOD}_{5}$ removal and 147.59 for energy consumption) indicates that most of the variation in the response can be explained by the regression equations. The associated $p$ value is used to estimate whether $F$ is large enough to indicate statistical 
significance. The values of Prob $>F<0.05$ indicated that model terms are significant. Prob $>F$ values are $<0.0001$ for turbidity removal, COD removal, $\mathrm{BOD}_{5}$ removal and energy consumption, which indicate that terms are significant at $95 \%$ probability level (Prakash Maran et al. 2013b). Coefficients of determination $\left(R^{2}\right)$ were found as 0.9983 , $0.9975,0.9974$ and 0.9933 , whereas adjusted $R^{2}$ were determined as $0.9967,0.9950,0.9947$ and 0.9865 for percentage turbidity, $\mathrm{COD}, \mathrm{BOD}_{5}$ removal and energy consumption, respectively, indicating a good fit for both dependent variables. For all equations, adequate precision signal to noise ratio is greater than 4 , which is desirable for sound models (Sridhar et al. 2012). The ANOVA results show that $j, \mathrm{pH}_{0}, c$ and $t$ are the significant factors that affect the turbidity, $\mathrm{COD}, \mathrm{BOD}_{5}$ removal and energy consumption by electrocoagulation. The model intercept coefficient, which does not depend on any factor, shows that the average percentage turbidity, $\mathrm{COD}, \mathrm{BOD}_{5}$ removal and energy consumption are $95.56 \%, 88.65 \%, 83.66 \%$ and $16.21 \mathrm{kWh} / \mathrm{m}^{3}$, respectively, and these values are independent of the factors set in the experiment. The ANOVA shows that the model chosen to explain the relationship between the factors and the response is suitable. Table 2 shows the relationship between the actual and the predicted values of $Y$, and it can be inferred that the residuals for the prediction of each response are minimum, supporting that the results of ANOVA are correct. The second-order polynomial equations for turbidity removal efficiency $\left(Y_{1}\right)$, COD removal efficiency $\left(Y_{2}\right), \mathrm{BOD}_{5}$ removal efficiency $\left(Y_{3}\right)$ and energy consumption $\left(Y_{4}\right)$ in terms of uncoded factors are given by Eqs. 3, 4, 5 and 6, respectively.

$$
\begin{aligned}
Y_{1}= & -149.66531+2.40129 X_{1}+44.57000 X_{2}+22.76333 X_{3} \\
& +3.06706 X_{4}-0.041208 X_{1}^{2}-3.67615 X_{2}^{2}-3.95833 X_{3}^{2} \\
& -0.034224 X_{4}^{2}+0.049625 X_{1} X_{2}-0.17850 X_{1} X_{3} \\
& -0.0063875 X_{1} X_{4}+0.0525 X_{2} X_{3} \\
& -0.012125 X_{2} X_{4}-0.0645 X_{3} X_{4} \\
Y_{2}= & -159.15656+2.61621 X_{1}+45.46708 X_{2} \\
& +22.13333 X_{3}+2.96615 X_{4}-0.045417 X_{1}^{2}-3.74260 X_{2}^{2} \\
& -4.30917 X_{3}^{2}-0.034289 X_{4}^{2}+0.018875 X_{1} X_{2} \\
& -0.12150 X_{1} X_{3}-0.0040125 X_{1} X_{4}+0.082500 X_{2} X_{3} \\
& -0.0055 X_{2} X_{4}-0.04475 X_{3} X_{4} \\
Y_{3}= & -163.99750+2.57679 X_{1}+46.30313 X_{2}+21.14542 X_{3} \\
& +2.89027 X_{4}-0.048021 X_{1}^{2}-3.87615 X_{2}^{2}-4.35458 X_{3}^{2} \\
& -0.033855 X_{4}^{2}+0.034250 X_{1} X_{2}-0.0995 X_{1} X_{3} \\
& -0.0031375 X_{1} X_{4}+0.21375 X_{2} X_{3} \\
& -0.001375 X_{2} X_{4}-0.045 X_{3} X_{4}
\end{aligned}
$$

$$
\begin{aligned}
Y_{4}= & +0.41667+0.068519 X_{1}-3.07523 X_{2}+1.81366 X_{3} \\
& +0.38022 X_{4}+0.010949 X_{1}^{2}+0.31192 X_{2}^{2} \\
& +3.37616 X_{3}^{2}-0.00515336 X_{4}^{2}+0.060417 X_{1} X_{2} \\
& -0.32708 X_{1} X_{3}+0.018576 X_{1} X_{4}-0.89583 X_{2} X_{3} \\
& +0.026389 X_{2} X_{4}-0.11250 X_{3} X_{4}
\end{aligned}
$$

The models predictions are compared with the experimental observations are shown in Fig. 6a-d. From the figures, it is observed that the developed models are adequate for the prediction of each response because the data points lie close to the diagonal line.

\section{Conclusion}

The effects of various operational parameters such as electrode distance, stirring speed, $\mathrm{NaCl}$ concentration, $\mathrm{pH}$ and current density on electrocoagulation using aluminum electrodes have been examined. The percentage turbidity, $\mathrm{COD}$ and $\mathrm{BOD}_{5}$ removal were found to increases with increasing electrolyte concentration, current density and stirring speed. The results showed that optimal operating conditions were found to be an initial $\mathrm{pH}$ of 6 , current density of $20 \mathrm{~mA} / \mathrm{cm}^{2}$, stirring speed of $150 \mathrm{rpm}, \mathrm{NaCl}$ concentration of $1.5 \mathrm{~g} / \mathrm{l}$ and electrolysis time of $30 \mathrm{~min}$. This experimental study clearly showed that under the optimal conditions, about $96 \%$ turbidity, $89 \%$ COD and $84 \% \mathrm{BOD}_{5}$ were successfully removed. Energy consumption and operating cost were found to decrease with increasing stirring speed and $\mathrm{NaCl}$ concentration and increased with an increase in current density, electrode distance, $\mathrm{pH}$ and electrolysis time. Under the optimal operating conditions, the energy consumption and operating cost were found to be $16.24 \mathrm{kWh} / \mathrm{m}^{3}$ and $2.7 \mathrm{US} \$ / \mathrm{m}^{3}$, respectively. A Box-Behnken design was successfully employed for experimental design and analysis of results for maximizing the turbidity, $\mathrm{COD}$ and $\mathrm{BOD}_{5}$ removal and for minimizing energy consumption. Analysis of variance showed a high coefficient of determination value $R^{2}=0.9983$ for turbidity, $R^{2}=0.9975$ for COD, $R^{2}=0.9974$ for $\mathrm{BOD}_{5}$ and $R^{2}=0.9933$ for energy consumption, thus ensuring a satisfactory fit of the secondorder regression model with that of the experimental data. The results of this study showed that electrocoagulation could be effectively used for the treatment of effluent generated from the egg processing plants.

Acknowledgments The authors are thankful to University Grant Commission, Government of India, for financial support (Grant No: 39-853/2010 (SR) dated 13.01.2011) for this experimental setup. 


\section{References}

Adhoum N, Monser L, Bellakhal N, Belgaied JE (2004) Treatment of electroplating wastewater containing $\mathrm{Cu}^{2+}, \mathrm{Zn}^{2+}$ and $\mathrm{Cr}(\mathrm{VI})$ by electro-coagulation. J Hazard Mater B112:207-213

Akyol A, Yatmaz HC, Bayramoglu M (2004) Photocatalytic decolourization of Remazol Red RR in aqueous $\mathrm{ZnO}$ suspensions. Appl Catal B Environ 54:19-24

Bayramoglu M, Kobya M, Can OT, Sozbir M (2004) Operating cost analysis of electrocoagulation of textile dye wastewater. Sep Purif Technol 37:117-125

Bayramoglu M, Kobya M, Eyvaz M, Senturk E (2006) Technical and economic analysis of electrocoagulation for the treatment of poultry slaughterhouse wastewater. Sep Purif Technol 51:404-408

Beltran de Heredia J, Dominguez JR, Lopez R (2004) Treatment of cork process wastewater by successive chemical-physical method. J Agric Food Chem 52:4501-4707

Bough WA (1975) Coagulation with chitosan-an aid to recovery of by-products from egg breaking wastes. Poult Sci 54:1904-1912

Bouhezila F, Hariti M, Lounici H, Mameri N (2011) Treatment of the OUED SMAR town landfill leachate by an electrochemical reactor. Desalination 280:347-353

Bully NR (1976) Egg processing waste recovery. Proceedings of the 6th National Symposium on Food Processing Wastes, EPA-600/ 2-76-224, Cincinnati. National Technical Information Service, Springfield, p 368-379

Chen G (2004) Electrochemical technologies in wastewater treatment. Sep Purif Technol 38:11-41

El-Ashtoukhy E-SZ, Amin NK, Abdelwahab O (2009) Treatment of paper mill effluents in a batch-stirred electrochemical tank reactor. Chem Eng J 146:205-210

Ersoy B, Tosun I, Gunay A, Dikmen S (2009) Turbidity removal from wastewaters of natural stone processing by coagulation/flocculation methods. CLEA004E-Soil, Air, Water 37(3):225-232

Greenberg AE, Connors JJ, Jenkins D, Franson MA (1995) Standard methods for the examination of water and wastewater, 15th edn. American Public Health Association, Washington

Harris CE, Moats WA (1975) Recovery of egg solids from egg grading and breaking plants. Poult Sci 54:1518-1523

Holt PK, Barton GW, Mitchell CA (2005) The future for electrocoagulation as a localized water treatment technology. Chemosphere 59:355-367

Kalyuzhnyi S, Gladchenko M, Starostina E, Shcherbakov S, Versprille A (2005) Combined biological and physico-chemical treatment of baker's yeast wastewater. Water Sci Technol $52: 175-181$
Kobya M, Delipinar S (2008) Treatment of the baker's yeast wastewater by electrocoagulation. J Hazard Mater 154:1133-1140

Minhalma M, Dominguez JR, De PinhoCork MN (2006) Processing wastewaters treatment by an ozonization/ultrafiltration integrated process. Desalination 191:148-152

Modirshahla N, Behnajady MA, Kooshaiian S (2007) Investigation of the effect of different electrode connections on the removal efficiency of tartrazine from aqueous solutions by electrocoagulation. Dyes Pigm 74:249-257

Mollah MYA, Schennach R, Parga JP, Cocke DL (2001) Electrocoagulation (EC)-science and applications. J Hazard Mater 84:29-41

Prakash Maran J, Sivakumar V, Sridhar R, Thirugnanasambandham K (2013a) Development of model for barrier and optical properties of tapioca starch based edible films. Carbohydr Polym 92:1335-1347

Prakash Maran J, Sivakumar V, Sridhar R, Prince Immanuel V (2013b) Development of model for mechanical properties of tapioca starch based edible films. Ind Crops Prod 42:159-168

Sridhar R, Sivakumar V, Prince Immanuel V, Prakash Maran J (2011) Treatment of pulp and paper industry bleaching effluent by electrocoagulant process. J Hazard Mater 186(2-3):1495-1502

Sridhar R, Sivakumar V, Prince Immanuel V, Prakash Maran J (2012) Development of model for treatment of pulp and paper industry bleaching effluent using response surface methodology. Environ Prog Sustain Energy 31(4):558-565

Tchamango S, Nanseu-Njiki CP, Ngameni E, Hadjiev D, Darchen A (2010) Treatment of dairy effluents by electrocoagulation. Sci Total Environ 408(4):947-952

Un UT, Ugur S, Koparal AS, Ogutveren UB (2006) Electrocoagulation of olive mill wastewaters. Sep Purif Technol 52:136-141

Xu LJ, Sheldon BW, Carawan RE, Larick DK, Chao AC (2001) Recovery and characterization of by-products from egg processing plant wastewater using coagulants. Poult Sci 80:57-65

Xu LJ, Sheldon BW, Larick DK, Carawan RE (2002) Recovery and utilization of useful by-products from egg processing wastewater by electrocoagulation. Poult Sci 81:785-792

Yavuz Yusuf (2007) EC and EF processes for the treatment of alcohol distillery wastewater. Sep Purif Technol 53:135-140

Zaied M, Bellakhal N (2009) Electrocoagulation treatment of black liquor from paper industry. J Hazard Mater 163:995-1000

Zhang J, Giorno L, Drioli E (2006) Study of a hybrid process combining PACs and membrane operations for antibiotic wastewater treatment. Desalination 194:101-107 